\title{
ЛIТЕРАТУРОЗНАВСТВО
}

УДК 82.091

DOI: http://dx.doi.org/10.30970/fpl.2020.133.3187

\section{ТОПОЛОГІЧНИЙ ЗМІСТ КОРЕЛЯТУ СТРАЖДАННЯ У ТВОРАХ СУЧАСНОЇ СВІТОВОЇ ЛІТЕРАТУРИ}

\author{
Фелікс Штейнбук
}

\author{
Університет Коменського у Братиславі, \\ площа Шафарика 6, Братислава, Словаччина, 81499 \\ e-mail:feliks.shteinbuk@uniba.sk
}

У статті на основі нових підходів, побудованих на інтеграції можливостей тілесно-міметичного методу аналізу художніх творів і топології, а також на прикладі репрезентативних творів сучасної світової літератури, зроблено спробу визначити топологічний зміст такого тілесного кореляту, як корелят страждання. Доведено, що топос страждання на теперішньому етапі літературного розвитку зазнає кардинальних змін аж до дисипації та діалектично зумовленого зникнення, але при цьому продовжує зберігати у собі суттєвий ідейно-художній потенціал, який забезпечує можливість сучасній літературі не втрачати філософської значимості, естетичної переконливості та емоційної сили. Натомість запропонований підхід виявляє неабияку дослідницьку перспективу, оскільки дає змогу результативно інтерпретувати не тільки вітчизняні, а й перекладні твори, і тому у майбутньому може бути поширеним на інші подібні кореляти.

Ключові слова: сучасна світова література, тілесно-міметичний метод, корелят, топос, страждання, дисипація.

Вступ. Літературознавство, будучи наукою про (не-)розуміння художнього тексту [25, с. 23], завжди потребувало ефективних шляхів та методів, які дозволяли б цій науці бути домірною до свого покликання. Та особливо загострилася окреслена проблема на сучасному етапі, і тому, вочевидь, виникла нагальна необхідність щодо відповідних теоретико-методологічних пропозицій.

Найбільш вимовно і ємно про непросту ситуацію у сучасній гуманітаристиці висловилася одна з редакторів російського часопису "Новое литературное обозрение" О. Тимофеєва, яка цілком слушно зазначила, що “повсякчасні розмови про вичерпаність гуманітарних наук $<\ldots>$ можуть розглядатися $<\ldots>$ як такі, що містять у собі доволі важливу інтуїцію”, відповідно до якої “вичерпаними виявляються не гуманітарні науки, а традиційні антропоцентричні риторичні моделі, що зумовлюють, так би мовити, ідеологічний апарат гуманітарного знання. Та якраз са́ме цей апарат, функціонування якого постійно встановлює і відновлює ієрархічні бінарності та моделі вищості «людського» щодо «тваринного», «чоловічого» щодо «жіночого», «білого» щодо «чорного» і т. д., є наразі безнадійно застарілим...” [18].

Штейнбук Ф., 2020 
Отже, на думку О. Тимофеєвої, “класична людина з ії необмеженою владою над світом перетворюється на нелегітимну конструкцію, але гуманітарне знання [все ж таки] здатне пережити свою ідеологію, знайти нові, неантропоцентричні перспективи власного розвитку вже з іншого боку самого себе і у такий спосіб розширити свої кордони" [18].

Аналіз останніх досліджень і публікацій. Одна з цих перспектив вбачається, зокрема, у так званому антропологічному повороті, зміст якого лаконічно визначила українська філософиня О. Гомілко, і який полягає, за словами останньої, у тому, що "філософська антропологія вводить феномен тілесності до кола необхідних якостей людини”, внаслідок чого “тілесність стає тим, що відтепер не може обминути мислення, котре конструює метафізичну версію людського буття” [3, с. 14; див. про це також 13].

Відповідно, закономірними ознаками антропологічного повороту безпосередньо у літературознавстві $є$ те, що цей поворот, з одного боку, “пропонує порушити дисциплінарні границі" [14, с. 35], а з іншого - змушує не “зупинятися на тому, про що тексти говорять на рівні прямого висловлювання або на рівні своєї граматичної та риторичної структури. Більш цікаве питання - про що тексти мовчать, але у чому можна спробувати почути людське мовлення, занурене у соціальний праксис так само, як і у власне несвідоме...” [6, с. 52].

Методологія дослідження. Окреслену зацікавленість можна задовольнити остільки, оскільки існує реальна можливість спертися на попередньо розроблений тілесно-міметичний метод аналізу художніх творів як метод аналізу тілесно-буттєвого підгрунтя художнього дискурсу [24: 122-123], який було обгрунтовано на основі поняття “тілесний міметизм" - поняття, що визначає один зі способів репрезентації тілесного буття людини у художньому дискурсі за посередництвом механізму мімезису та через концептуалізовані у філософському контексті тілесні кореляти, які становлять основу для творення складної і динамічної образної системи художнього твору [23, с. 259-271].

Це передусім може означати, що будь-яка тілесна категорія набуває в умовах художнього дискурсу характер топосу, який "у сучасних дослідженнях $<\ldots>$ має два основних тлумачення. По-перше, це вагоме для художнього тексту (або групи художніх текстів - напрямку, епохи, національної літератури загалом) «місце розгортання сенсів», яке може корелювати з будь-яким фрагментом (або фрагментами) реального простору, як правило, відкритим. [I] по-друге, це «загальне місце», набір сталих мовленнєвих формул, а також спільних проблем та сюжетів, характерних для національної літератури" [15, с. 89].

За такої перспективи мета статті полягає у тому, аби на прикладі декількох репрезентативних творів, які належать до відмінних культурних дискурсів, визначити топологічний зміст такого тілесного кореляту, як корелят страждання, тому що цей корелят характеризується крайньою, але водночас як універсальною, так і традиційною формою ментально-тілесного стану, зображення якого у сучасній літературі зазнало, проте, суттєвих змін. 
Результати дослідження та їхнє обгрунтування. Зокрема, у романі французького письменника Ф. Бегбеде "Романтичний егоїст" не обійшлося без епатажу та відвертих сцен, і це навряд чи може здивувати, оскільки творчість Ф. Бегбеде вмотивовано можна вважати цілком репрезентативною щодо певного мейнстріму в сучасній літературі, присвяченій проблемі відчуження людини від світу і представленій книгами, скажімо, британця Б. Елтона, американців Ч. Паланіка і Б. Істона-Елліса або й співвітчизника Ф. Бегбеде М. Уельбека.

Натомість дивує інше: поєднання у назві явищ, в засаді, непоєднуваних, бо прозорий оксюморонний кшталт симбіозу “романтичності” та “егоїзму” не потребує навіть якихось додаткових чи особливих коментарів.

Відповідно, зміст твору надає цій парадоксальній назві ще більшої гостроти, у тому числі й через притаманні роману Ф. Бегбеде епатаж і відвертість на межі, а подекуди й поза межею фола. Крім цього, як з'ясувалося, топос сексуальності, що здоміновує наративну стратегію і сюжетику цього твору, у дивовижний спосіб корелює 3 топосом страждання, яким "Романтичний егоїст" не просто наснажується, а яким роман $є$ просякнутим вщерть, у зв’язку з чим звернення до аналізу топосу страждання у цьому творі здається і необхідним, і доцільним.

Передусім варто зазначити, що, попри незаперечну кореляцію між топосами болю та страждання, між ними все ж таки існує принципова відмінність навіть 3 медичної точки зору. У цьому контексті біль визначається як “відчуття загрози або пошкодження біологічної цілісності індивідууму”, а страждання розглядається як “наслідок отриманої або такої, що триває, руйнації особистості чи ії значної частини”. Сказати б інакше, страждання потрактовується як “випробування, пов'язане з пошкодженням інтегративної цілісності особистості, і становить психологічну характеристику, що репрезентує суб'єктивне відчуття особистості («я»)" [4].

Наведеним уявленням про страждання вторують, а заразом надають їм додаткових сенсів і постулати філософів, які вважають, що “у стражданні порушуються символічні межі світу та самості: страждання відкриває доступ до іншого світу, безмір якого загрожує знищити самість...” [22].

Проте, певно, найбільш розробленою проблематика страждання постає у релігійномудискурсі,причомунезалежновіддоктрин, якілежатьвоснові різноманітних конфесій - від язичництва до світових релігій. Так, наприклад, щодо юдаїзму, то “... мудреці у Талмуді < . .> повчали, що страждання $є$ неоднозначним за своєю сутністю”, оскільки “воно рідко буває або тільки покаранням, або випробуванням, або спробою виправлення життєвої позиції людини”. Та “найбільш вагомим вони вважали те, що <..> переживши страждання, люди стають кращими” [20]. А у Мідраші, себто у книзі, яка тлумачить Біблію, можна знайти навіть афоризм з цього приводу, за яким “якщо не зазнати страждання, то неможливо стати й справжньою людиною”.

Цілком суголосним юдейській позиції є ставлення до страждання і у християнстві у тому сенсі, що страждання розглядається як обов'язкова умова, яка передує спасінню у Царстві Небесному. Наприклад, російський християнський публіцист, богослов i проповідник В. Марцинківський, який, щоправда, народився у Волинському селі 
Дермань, пристрасно переконував у тому, що “страждання є для нас джерелом моральних цінностей і позитивних духовних надбань, воно веде нас до віри, любові та духовної сили”, а також “робить нас не лише кращими, а й випрацьовує у нас здатність робити кращими інших" [9].

Відповідно, К. Льюїс - один 3 оригінальних богословів за сумісництвом, бо він більше відомий як автор фентезійного циклу “Хроніки Нарніі”, - дозволив собі ствердити, що “страждання - це мегафон Божий”, адже ми, мовляв, “можемо не зауважувати наших гріхів, дурниць і навіть задоволень (згадайте, як безглуздо їсть ненажера найсмачніші страви), але не помітити страждання просто неможливо" [8].

Схожу поставу щодо страждання знаходимо і в ісламі. Зокрема, у цій релігії акцентовано увагу на необхідності за прикладом Пророка Мухаммада вибачати тим, хто спричинює страждання [див., наприклад, 16]. Натомість у буддизмі сам засновник цієї релігії Будда Шакьямуні сформулював 3 приводу страждання базове вчення про чотири благородні істини (чатварі ар'ясатьяні), за якими страждання існують, причиною страждання є бажання, страждання припиняється через досягнення нірвани, а шлях, що провадить до припинення страждання, визначається як восьмеричний шлях.

I, нарешті, у цьому контексті варто також згадати ставлення до проблеми страждання засновника логотерапії, себто методу екзистенціального психоаналізу, австрійського психіатра В. Франкла, який пережив трирічне ув'язнення у нацистських концтаборах, а отже, добре знався на цьому предметі не з книг або з чуток, а з власного досвіду.

Отож ця мужня людина вважала, що “страждання спричинює плідне < ..> духовне напруження, яке має здатність...” кардинально трансформувати навіть фундаментальні людські уявлення. Щобільше, на думку В. Франкла, “мета страждання полягає у тому, аби захистити людину від апатії, від духовного задубіння”, оскільки, на його глибоке переконання, “смисл страждання - звісно, лише неминучого страждання, - $\epsilon$ найглибшим з усіх можливих смислів” [21].

Отже, якщо підсумувати наведені вище максими, то, попри різноманітність запропонованих сентенцій, можна дійти узагальнено-концептуального висновку, а са́ме:

1) страждання має універсальний характер і у плані широти розповсюдження, і у плані глибини вияву;

2) через те, що страждання є обов'язковим субститутом, який жодній людині, що живе, оминути неможливо, йдеться, власне, про онтологічний, буттєвий корелят;

3) нездатність людини елімінувати страждання зі свого життя призводить до необхідності надати стражданню бодай якийсь сенс;

4) сенс страждання у діалектичний спосіб вбачається у тому, що воно, попри свій, в засаді, негативний кшталт, є корисним, а навіть необхідним для того, аби людина стала кращою, сильнішою, більш терпимою, благородною, а надто ще й - мудрою і “справжньою”.

Отже, навіть якби людина і не була б приреченою на страждання, то його за будь-яку ціну треба було б все ж таки вигадати. Втім, на щастя (?!), у цьому немає 
жодної потреби, і тому залишається тільки надати стражданню форму гіпостазованої інакшості, аби можна було без найменших сумнівів оперувати цим корелятом і у рамках релігії, і у межах філософії, i, звісно, у дискурсі художньої літератури.

В останньому ж випадку, з огляду на специфіку літературної творчості, топос страждання може набувати вже й зовсім карколомного, або ж протиприродного чи й перверсійного штибу. Принаймні у романі Ф. Бегбеде "Романтичний егоїст” прикладів, які ілюструють цю тезу, починаючи вже з перших сторінок, чимало, проте ці вияви страждання і справді мають своєрідний характер.

Наприклад, головний герой-оповідач Оскар Дюфрен переймається через те, що відтепер він буде “...змушений ненавидіти та скиглити у «VSD» щоп’ятниціщосуботи-щонеділі” [2, с. 8], оскільки йому запропонували вести колонку у цьому розважальному тижневику, себто у “VSD”. Або ж, гостюючи у друзів на острові Ре (“Що за дурна назва!” [2, с. 11]), Дюфрен не перестає бідкатися, бо “замість того, аби 3 кимсь злягатися, [він] чита[є] листування Флобера” [2, с. 12]. Врешті-решт, вештаючись “пустинним Парижем” [2, с. 20] і згадавши певний вислів Ж.-Ж. Руссо 3 “Нової Елоїзи” останнього, оповідач вдається до парафразу і доходить висновку, відповідно до якого “щасливими ми буваємо лише напередодні щастя; потім - потік лайна" [2, с. 21].

Звісно, на перший погляд може видатися, що вважати усі ці нарікання виразами страждання $\epsilon$ не надто виправданим перебільшенням. А тому буцімто більш переконливо звучить, скажімо, теза, за якою “розумний європеєць, що біситься з жиру $<\ldots>$ цілком свідомий того, що життя, яке він провадить, є неправильним, порочним і просто злочинним. Отож він усвідомлює це, відмовляється від такого життя на словах, кляне його і - продовжує у тому ж таки дусі” [17].

Водночас, на думку Д. Суботіна, твори Ф. Бегбеде не тільки про це, а також ще й “про ідіотські спроби протесту, бунту проти самого себе і проти системи, яка породила такого «самого себе»” [17]. А це означає, що у романі французького письменника мають місце умови, які об'єктивно сприяють поставанню страдницького, так би мовити, дискурсу. Бо якби Оскар Дюфрен був цілковито задоволеним з описуваного ним способу життя і хоча б на словах не ганив і самого себе, і всіх довкола, то тоді й говорити не було б, далебі, про що.

Натомість залишатися у спокої через наїжене донесхочу сьогодення головний герой не має змоги, а до того ж цей стан перманентної тривоги суттєво посилюється через нещасливе кохання, яке, попри свій іронічний штиб - адже Франсуаза, кохана Оскара, надала перевагу не іншому чоловіку, а іншій жінці, - змушує розповідача визнати, що “ніколи в житті [він] так не страждав, ніколи” [2, с. 276].

Отже, протагоніст не просто посипає собі (й іншим) голову попелом через те, що солодке життя набридло йому більше, ніж гірка редька, - у романі пропонується дещо відмінне від традиційного уявлення про зміст страждання. Навряд чи існує потреба повторювати, у чому полягають стереотипи щодо підстав для визначення страждання, бо ці підстави є очевидними, і тому в аналізованому творі спосіб життя головного героя нібито заперечує можливість кваліфікувати його стан як стан страждання. Втім виявляється, що багаті можуть не тільки плакати, а й страждати, тому що останнє 
залежить аж ніяк не від рівня матеріального забезпечення і не від суспільних обставин, у яких екзистує та чи інша особистість.

Щобільше, за твердженням Г. Гейне, “страждання, хай навіть і уявні, завдають не менший біль”, проте і з реальними, чи то пак з традиційними, стражданнями ситуація виглядає дещо складніше, ніж видається на перший погляд.

Отож дехто з фахівців “пропонує розрізняти «лімінальні» і «ліміноїдні» символічні форми вираження”, не без підстав вважаючи, що “так само, як лімінальні ритуали архаїчного суспільства, ліміноїдні практики індустріального соціуму призначені для символічного подолання досвіду переходу, трансформації і кризи”. Принципова відмінність між лімінальними та ліміноїдними формами полягає, натомість, у тому, що останні є “пристосованими до потреб індивідів, які звільнилися (в ході економічних перетворень суспільства і диференціації праці та гри) від ланцюгів колективних зобов'язань”. А відтак “стає зрозумілим процес «сучасної» символічної переробки страждання: усвідомлення кризи набуває характер особистого усвідомлення, а позбутися страждань можна лише через власні зусилля, тобто самоідентифікація через страждання в умовах сьогодення перетворюється на мовотворчий акт, право на який змушений реалізовувати передусім сам індивід” [22].

Наведена трактовка страждань в актуальному світі цілком вписується і в категорії фрактального патерну, оскільки “взірцеве”, так би мовити, страждання, притаманне попереднім епохам, ніби розбивається і подрібнюється на патерни страждання, які надзвичайно важко, - хоч все ж таки і можливо, - ідентифікувати у відповідний спосіб. Крім цього, такі патерни тяжіють до дисемінації чи, точніше, до дисипації і постають у розпорошеному та неавтентичному вигляді, внаслідок чого і виникають щойно згадувані проблеми з чітким визначенням досліджуваного топосу.

Причому окреслені характеристики топосу страждання стосуються не тільки одного твору чи творчості одного митця - 3 досить високою долею ймовірністю можна припустити, що подібний механізм функціонує також і в інших творах сучасної літератури.

Отже, спробуємо підтвердити чи спростувати цю тезу.

Немає жодних сумнівів у тому, що першим відповідним “бранц[ем] власної писемності” [5, с. 261] є, вочевидь, оповідач у книзі Ю. Іздрика “Таке”. Прикметно, що й дискретна (подрібнена?) композиція обох творів $є$ майже подібною і відрізняється тільки тим, що у романі Ф. Бегбеде існує все ж таки хоч якийсь натяк на сюжет. Натомість у книзі Ю. Іздрика навіть такого натяку дошукатися вкрай важко, але у “Такому” більш виразно і яскраво дається взнаки топос страждання, який фактично домінує у цьому тексті та забезпечує необхідний простір для алогічних, сливе не пов'язаних між собою вибухів рефлексивного художнього лементу.

За такої перспективи стає зрозумілим, чому, на думку наратора, “наша доля це порожнеча, знеструмленість і зосередженість”, чому “світ - це випалена пустеля жорстокого відхідняка...” і чому “світова культура так нагадує засраний пристанційний нужник..." [5, с. $10,32,184]$. Бо ж як може бути інакше, коли оповідач навіть “не в шоці” - він “просто в а́хуї”, а проте, як виявляється, “і цей [його] текст - лише чергова спроба вистояти, встояти, втриматися” [5, с. 68] - спроба, треба визнати, цілком вдала. 
Адже, попри те, що слова “складаються не з літер чи звуків, а з уламків потрощених сутностей” [5, с. 267], оповідач спромігся поєднати все це у “Таке”... собі текстуальне шаленство, інспіроване страдницьким світовідчуттям, що цим шаленством, либонь, $\mathrm{i}$ долається.

Топос страждання вагомо визначає і зміст роману М. Уельбека "Можливість острова” хоча б тому, що, на думку одного з героїв-клонів, здається, Даніеля 25, “життя людства на загал проходи[ть] <...> під знаком страждання, з окремими, завжди надто короткими моментами задоволення..." [19, с. 369].

Цей відсторонено-філософський погляд, який належить, так би мовити, до продукту “Стандартної Генетичної Ректифікації”, внаслідок застосування якої “трансформована <..> людська істота [отримує можливість] жити за рахунок сонячної енергії, а також води і невеликої кількості мінеральних солей...” [19, с. 290], - знаходить підтвердження і в історії, яку розповідає предок цієї людиноподібної істоти, себто Даніель1.

Отож Даніель1, популярний французький комік, 3 одного боку, стає свідком страждання своєї другої дружини Ізабель, яка не змогла змиритися зі старінням i наклала на себе руки - “...штрикнула собі сильну дозу морфію” [19, с. 292]. А з іншого боку, головний герой і сам вдається до самогубства, оскільки теж не здатен погодитися ані $з$ тим, що перетворився на старигана, ані з тим, що його останнє кохання - молода актриса на ім’я Естер, збридила їхнім зв’язком і “....навіть мала намір звернутися до полиції...” [19, с. 332], аби позбутися його істеричних домагань.

Врешті-решт і вступ Даніеля1 до секти елохімітів був також вмотивованим надією на обіцяне безсмертя, проте парадокс полягає у тому, що коли ці мрії і справді збулися, то його далекий, двадцять п’ятий, нащадок нехтує спокійним трибом існування і вдається до втечі у реальний світ. Але і на цьому, себто на зворотному, шляху Даніель 25 доходить висновку, за яким тільки їхній собака Фокс - це “...єдин[а] відом[а] [йому] істота, що заслужила право жити далі...” [19, с. 377].

Отже, важко не зауважити, що між романами двох французьких авторів, принаймні у рамках досліджуваного топосу, є чимало спільного: їхні герої страждають, зокрема, через те, що їх залишили кохані жінки, і зі щасливих коханців вони перетворюються на жалюгідних нікчем. Проте є і принципова відмінність: Оскара Дюфрена ми залишаємо у ту мить, коли він сидить “....на задньому сидінні безшумного лімузину, який везе [його] до [його] кінця" [2, с. 281].

Натомість на те, аби розпрощатися 3 головним героєм роману М. Уельбека, фактично немає жодної ради, оскільки у фіналі Даніель, втілений у свою аж двадцять п’яту іпостась, сумно повідомляє про те, що йому “...залишилося жити, напевно, років шістдесят...”, упродовж яких він зобов'язується перед самим собою “уникати страждання" [19, с. 377].

Необхідно також вказати i ще на один парадокс: попри усю тематичну ексцентричність роману М. Уельбека, топос страждання репрезентовано у ньому не дискретно, як у романі Ф. Бегбеде, а континуально, і навіть, сказати б, насиченоконтинуально. Але разом з тим і у цьому творі автор не оминув застосування механізму, описуваного у категоріях фрактального патерну, що тяжіє до дисипації. 
Відмінність полягає тільки у тому, що у першому випадку цей механізм діє через інтенсифікацію наративу, за який відповідає лише один суб'єкт, а у другому випадку - через екстенсифікацію оповіді у тому сенсі, що їі розподілено між кількома нараторами, до яких належать, щонайменше: Даніель 1, Даніель24, Даніель25, а також Марія22.

Втім остаточно обидва романи спрямовуються до невтішного резюме, за яким на питання "Верховної Сестри” у “Другому Спростуванні Гуманізму”: “Доки будуть зберігатися передумови страждання?" - вона сама й відповідає таке: "Вони не зникнуть до тих пір, поки жінки будуть народжувати дітей” [19, с. 344].

Ще один приклад застосування насичено-континуального варіанту щодо розгортання топосу страждання репрезентовано у романі О. Памука "Музей невинності”. Але у цьому випадку автор застосовує, либонь, комбіновану стратегію, тобто, з одного боку, за наратив майже протягом усього тексту несе, так би мовити, відповідальність головний герой-оповідач Кемаль Басмаджи. Проте у фіналі ми дізнаємося про те, що цей герой “... знайшов вельмишановного Орхана Памука, який 3 [його - Кемаля] згоди та від [його - Кемаля] імені снує розповідь цієї книжки” [11, c. 643].

За таких обставин стає зрозумілим, чому, попри “роки страждання" [11, с. 470], які змушені були пережити і Кемаль, і Фюсун, у нас не виникає враження, що у романі йдеться про героїв-мучеників: адже цю історію від першої особи розповідає стороння людина.

Водночас таке делегування наративних повноважень призводить до того, що страждання у певному сенсі перетворюється на свою протилежність - на джерело радості, а навіть сповненого неабияким сенсом щастя, яке зазнає куратор Музею невинності і про яке він свідчить у фіналі твору, переможно сповіщаючи передусім самого себе, а також О. Памука i, звісно, всіх зацікавлених про те, що він “...прожив напрочуд щасливе життя" [11, с. 666].

Відповідно, дискурсивна неактуальність топосу страждання в інших, вибраних для аналізу творах, додає до розуміння характеру функціонування цього топосу ще декілька виразних рис. Зокрема, відсутність топосу страждання у книзі Я. Вишневського "Коханка", попри наявність у текстах новел вкрай болючих історій, можна пояснити, зокрема, тим, що, на відміну від роману Ф. Бегбеде, у якому герой проминає рівень болю і відразу починає страждати, біль, який переживають персонажі Я. Вишневського не переходить у хронічну форму, себто на рівень страждання, адже і болю їм цілком вистачає, аби усвідомити певні вагомі буттєві сенси і аби повернутися до самих себе, до своєї самості.

Натомість у випадку з героями романів С. Поваляєвої «Замість крові» $\mathrm{i}$ Н. Сняданко «Колекція пристрастей, або Пригоди молодої українки» неактуальність топосу страждання вмотивовується цілком природними причинами, відповідно до яких персонажі просто через свою молодість не встигають перейти на рівень страждання, бо, наприклад, Дред ставить крапку са́ме у тому пункті, у якому, власне, і мала б розпочатися історія його страждань. Та це вже, прецінь, інша історія. 
Дещо інакше, бо у цілком свідомий і цілеспрямований спосіб, долають топос страждання, аби не сказати нехтують ним, М. Павич та С. Рушді. Отож ці письменники звертаються не до особистого, а до історичного минулого і виступають у ролі своєрідних, сказати б, дискурсивних дослідників, внаслідок чого біль і страждання не надто вписуються у їхні розвідки, навіть попри те, що С. Рушді для створення казково-історичної феєрії у романі “Флорентійська чарівниця” обирає цілком відчужену й безпристрасну наративну стратегію, а М. Павич у романі “Друге тіло”, навпаки, надає перевагу більш особистісному стилю, спрямованому, втім, на пошуки розгадки напівмістичної і напівфілософської таємниці того ж таки “другого тіла".

Звісно, це аж ніяк не означає, що, зробивши свій вибір на користь казкової або напівказкової проблематики, ці автори не змогли б за бажанням розгорнути у своїх творах топос болю або топос страждання. Проте якщо навіть погодитися з думкою В. Франкла, відповідно до якої страждання “становить невід'ємну частину життя людини, оскільки походить з самої їі сутності і сенсу” [21], то і тоді навряд чи є підстави присутність відповідного топосу у художньому дискурсі визнавати неминучою. Щобільше, відсутність цього топосу у певних текстах об’єктивно засвідчує намагання авторів ще й у такий спосіб заперечити та подолати приреченість людини на біль $\mathrm{i}$ страждання.

Слушність останньої тези певним чином доводить відсутність розгорнутого топосу страждання й у романі японського письменника X. Муракамі “1Q84”. У цьому творі, драматичний зміст якого буцімто мав би неминуче зумовлювати наявність у тексті книги відповідного, тобто страдницького, топосу, останній також не актуалізується. Та навряд чи цей парадокс пояснюється свідомою установкою автора у цьому випадку радше спрацьовує інший чинник, який стосується вже національних особливостей, характерних для японської культури, що виразно репрезентується, зокрема, афоризмом, за яким страждання вважається насінням радості.

I справді, протагоністи Аомаме і Тенго, які зазнали неабияких страждань та які мужньо і без зайвого афішування довго зносили їх, у фіналі роману обдаровуються довгоочікуваною зустріччю, “...3’єднавшись в одне ціле...” [10, с. 540].

Натомість у романі В. Пелевіна також даються взнаки національні особливості, які, зокрема, стосуються подолання не лише страждань, а й традиційного ставлення до літератури як до певної сакральної сутності, оскільки, як з'ясовується з розмови містичного персонажа на ім'я Аріель і головного героя графа Т. у романі “T”, колись “...писатель впитывал в себя, фигурально выражаясь, слёзы мира, а затем создавал текст, остро задевающий человеческую душу $<\ldots>$ Но сейчас $<\ldots>$ от писателя требуется преобразовать жизненные впечатления в текст, приносящий максимальную прибыль. Понимаете?” [12, с. 89]. Звісно, зрозуміло, що за такої навіть не іронічної, а гротескно-саркастичної перспективи страждання нівелюється, а отже, і заперечується так само, як і будь-які інші спроби говорити серйозно про серйозні речі.

Отже, 3 усіх обраних для аналізу творів тільки у романі В. Кучока "Гівнюк" різноманітний біль, якого повсякчас зазнає головний герой-розповідач, становить 
основу для розгортання топосу страждання, тому що катування цього героя не обмежуються у просторі і часі.

Щобільше, біль, який завдає головному герою оточення, якраз і спрямований на те, аби перетворити існування хлопця на суцільний жах, що не вичерпується або родинною домівкою, або школою, або так званим санаторієм, позаяк навіть шлях до школи чи не щодня перетворювався для бідолахи-оповідача, без перебільшення, на хресну путь, яка закінчувалася тим, що коли він все ж таки потрапляв до школи, то “друзяки повідомляли [його]: «Знову ти весь обхарканий на плечах», бо хахари зі Штайнки < ..> плювали [йому] на плечі...” [7, с. 73].

Чи є хоч найменший шанс, аби подолати таке тотальне страждання? Чи достатньо для цього визнати, наприклад, що “...сум [хлопця] обернеться в радість!” (Ів. 16: 20)? Або чи вистачить, скориставшись, наприклад, інтенцією Г. Башляра, порадити небозі почитати Ш. Бодлера, “царствене” слово якого “вчить нас дихати тим повітрям, яке спочиває над виднокраєм, вдалині від стін химеричних в’ язниць, що так нас лякають” $[1$, с. 171$] ?$ !

Вочевидь, ці питання є риторичними, а тому й не дивно, що наприкінці роману символ страждання - стару батьківську кам'яницю, поглинає потік лайна, а оповідач стверджує ніби щось не надто зрозуміле, мовляв, “я був, мене вже нема” [7, с. 142].

Втім за окресленої перспективи зникнення (хоча б дискурсивне) - це, либонь, чи не єдиний спосіб на подолання страждання, яке має абсолютний вимір. Водночас таке зникнення можна інтерпретувати ще і як остаточний результат дисипації, що досягається не за посередництвом поетикальних засобів, як, наприклад, у романах Ф. Бегбеде чи Ю. Іздрика, а у відверто декларативний спосіб.

Висновки та перспективи подальших досліджень. Таким чином, “факт залишається фактом: поезія несе у собі своє власне щастя, незалежно від того, які страждання вона покликана ілюструвати" [1, с. 18].

А отже, немає особливого значення, чи страждання долається через безпосереднє заперечення, внаслідок якого цей топос просто не береться до уваги у дискурсі, чи - у діалектичний спосіб, завдяки чому страждання обертається на свою протилежність, себто на щастя, чи, врешті-решт, - у спосіб декларативний, бо набагато більш важливим $\epsilon$ те, що за будь-яких обставин в аналізованих текстах неможливо знайти зразки примирення зі стражданням.

Навпаки, різноманітні патерни цього топосу повсякчас заперечуються, а, натомість, будучи присутніми у текстах, насичують дискурс глибоким драматизмом, вагомими сенсами і надзвичайно вразливою чутливістю, причому навіть тоді, коли йдеться не тільки про "Романтичного егоїста" або “Можливість острова", а й, наприклад, про "Гівнюка".

Отже, з одного боку, аналіз окремих творів сучасної світової літератури у контексті репрезентації в них топоса страждання дозволяє дійти також висновку і про те, що шуканий традиційний корелят на теперішньому етапі літературного розвитку зазнає кардинальних змін аж до дисипації та діалектично зумовленого зникнення. Але при цьому продовжує зберігати у собі суттєвий ідейно-художній потенціал, який дозволяє 
сучасній літературі не втрачати філософської значимості, естетичної переконливості та емоційної сили.

Натомість, з іншого боку, запропонований підхід виявляє неабияку дослідницьку перспективу, адже дозволяє результативно аналізувати не тільки вітчизняні, а й перекладні твори, і тому у майбутньому може бути поширеним на інші подібні кореляти.

\section{СПИСОК ВИКОРИСТАНИХ ДЖЕРЕЛ}

1. Башляр Г. Избранное: Поэтика пространства. Москва : Российская политическая энциклопедия (РОССПЭН), 2004. 376 с.

2. Бегбеде Ф. Романтичний егоїст. Харків : Фоліо, 2007. 283 с.

3. Гомілко О. Метафізика тілесності. Дослідження, розвідки, екскурси. Київ : Наукова думка, 2001. 338 [2] с.

4. Данилов А. Б. Страдание и хроническая боль. Русский медицинский журнал. 2008. Tом 16. URL: http://paininfo.ru/articles/2549.html.

5. Іздрик. Таке. Харків : Клуб сімейного дозвілля, 2010. 272 с.

6. Калинин И. Время кризиса и бремя манифестов. Филология на повороте. Новое литературное обозрение. 2012. № 113. С. 47-52.

7. Кучок В. Гівнюк (Антибіографія). Львів : Кальварія, 2007. 144 с.

8. Льюис К. С. Страдание. URL: https://www.pravmir.ru/stradanie/.

9. Марцинковский В. Смысл страдания. URL: http://www.pobedish.ru/main/pain?id=171.

10. Муракамі Х. 1Q84. Харків: Фоліо, 2009-2011. Кн. 3. 2011. 543 с.

11. Памук О. Музей невинності. Харків : Фоліо, 2009. 671 с.

12. Пелевин В. О. Т. Москва : Эксмо, 2009. 384 с.

13. Подорога В. Феноменология тела. Москва : Ad Marginem, 1995. 301 с.

14. Поселягин Н. Антропологический поворот в российских гуманитарных науках. Новое литературное обозрение. 2012. № 113. С. 27-36.

15. Прокофьева В. Ю. Категория пространства в художественном преломлении: локусы и топосы. Вестник Оренбургского университета. 2005. № 11. С. 87-94.

16. Саадуев М. В чём смысл страданий Пророка Мухаммада (салляллаху аляйхи васаллям)? URL: http://islamdag.ru/verouchenie/7008.

17. Субботин Д. PR для апокалипсиса. Скепсис. 2005. № 3/4. URL: http://scepsis.net/ library/id 400.html.

18. Тимофеева О. От редактора. Новое литературное обозрение. 2012. № 114. URL: http:// magazines.russ.ru/nlo/2012/114/t2-pr.html.

19. Уельбек М. Можливість острова. Харків : Фоліо, 2007. 414 с.

20. Форт А. Иудаика. URL: http://istok.ru/library/learn-n-teach/posobiya/jeduizm-forta/ jeduizm-forta 117 .html.

21. Франкл В. О смысле страдания. URL: http://www.pobedish.ru/main/pain?id=149.

22. Хайдарова Г. Боль в культуре. Подходы, концепции, комментарии. Аналитический обзор (Часть II). URL: http://paininfo.ru/articles/4292.html.

23. Штейнбук Ф.М.Засади тілесногоміметизму утекстових стратегіях постмодерністської літератури кінця XX - початку XXI століття. Київ : Педагогічна преса, 2007. 215 с.

24. Штейнбук Ф. М. Тілесність - мімезис - аналіз (Тілесно-міметичний метод аналізу художніх творів). Київ : Знання України, 2009. 292 с.

25. Ямпольский М. Филологизация. Новое литературное обозрение. 2005. № 75. C. 10-23. 


\section{REFERENCES}

1. Bashljar G. Izbrannoe: Pojetika prostranstva [Selected works: Poetics of space]. Moskva : Rossijskaja politicheskaja jencyklopedija (ROSSPEN), 2004. $376 \mathrm{~s}$.

2. Begbede F. Romantychnyi ehoist [A romantic egoist]. Kharkiv : Folio, 2007. $283 \mathrm{~s}$.

3. Homilko O. Metafizyka tilesnosti. Doslidzhennia, rozvidky, ekskursy [Metaphysics of corporality. Study, research, excursus]. Kyiv : Naukova dumka, 2001. 338 [2] s.

4. Danilov A. B. Stradanie i hronicheskaja bol [Suffering and chronic pain]. Russkij medicinskij zhurnal. 2008. Tom 16. URL: http://paininfo.ru/articles/2549.html.

5. Izdryk Y. Take [Such like]. Kharkiv: Klub simeinoho dozvillia, 2010. $272 \mathrm{~s}$.

6. Kalinin I. Vremja krizisa i bremja manifestov. Filologija na povorote [Crisis time and manifest burden. Philology at a turn]. Novoe literaturnoe obozrenie. 2012. № 113. S. 47-52.

7. Kuchok V. Hivniuk (Antybiohrafiia) [A shithead (The anti-biography)]. Lviv : Kalvariia, 2007. $144 \mathrm{~s}$.

8. Liuis K. S. Stradanije [Suffering]. URL: https://www.pravmir.ru/stradanie/.

9. Marcinkovskij V. Smysl stradanija [Essence of suffering]. URL: http://www.pobedish.ru/ main/pain?id=171.

10. Murakami Kh. 1Q84. Kharkiv: Folio, 2009-2011. Kn. 3. 2011. 543 s.

11. Pamuk O. Muzei nevynnosti [The museum of innocence]. Kharkiv : Folio, 2009. $671 \mathrm{~s}$.

12. Pelevin V. O. T [T]. Moskva : Eksmo, 2009. 384 s.

13. Podoroga V. Fenomenologija tela [The phenomenology of the body]. Moskva : Ad Marginem, 1995. $301 \mathrm{c}$.

14. Poseljagin N. Antropologicheskij povorot $\mathrm{v}$ rossijskih gumanitarnyh naukah [An anthropological turn in Russian humanities]. Novoe literaturnoe obozrenie. 2012. № 113. S. 27-36.

15. Prokof'eva V. Y. Kategorija prostranstva v hudozhestvennom prelomlenii: lokusy i toposy [The category of space in artistic refraction: loci and topoi]. Vestnik Orenburgskogo universiteta. 2005. № 11. S. 87-94.

16. Saaduev M. V chem smysl stradanij Proroka Muhammada (salljallahu aljaihi vasalljam)? [What is the essence of Prophet Muhammad's suffering (salljallahu aljaihi vasalljam)?]. URL: http://islamdag.ru/verouchenie/7008.

17. Subbotin D. PR dlja apokalipsisa [PR for apocalypses]. Skepsis. 3/4. URL: http://scepsis. net/library/id_400.html.

18. Timofeeva O. Ot redaktora [From the editor]. Novoe literaturnoe obozrenie. 2012. № 114. URL: http://magazines.russ.ru/nlo/2012/114/t2-pr.html.

19. Uelbek M. Mozhlyvist ostrova [The possibility of an island]. Kharkiv : Folio, 2007. $414 \mathrm{~s}$.

20. Fort A. Iudaika [Iudaism study]. URL: http://istok.ru/library/learn-n-teach/posobiya/ jeduizm-forta/jeduizm-forta_117.html.

21. Frank V. O smysle stradanija [On the essence of suffering]. URL: http://www.pobedish.ru/ main/pain?id=149.

22. Hajdarova G. Bol v kulture. Podhody, konceptsii, kommentarii. [Pain in culture. Approaches, concepts, commentaries.]. Analiticheskij obzor. II. URL: http://paininfo.ru/articles/4292. html.

23. Shteinbuk F. M. Zasady tilesnoho mimetizmu u tekstovykh stratehiiakh postmodernistskoi literatury kintsia XX - pochatku XXI stolittia [Principles of corporal mimetism in text strategies of postmodernism literature at the end of XX - at the beginning of XXI century], Kyiv: Pedahohichna presa, 2007. 215 s. 
24. Shteinbuk F. Tilesnist-mimezys - analiz (Tilesno-mimetychnyi metod analizu khudozhnikh tvoriv) [Corporality - mimesis - analysis (Corporal-mimetic method to analyze fiction works)], Kyiv: Znannia Ukrainy, 2009. 292 s.

25. Jampolskij M. Filologizatsija [Filologization]. Novoe literaturnoe obozrenie. 2005. № 75. S. 10-23.

\title{
TOPOLOGICAL CONTENT OF THE SUFFERING CORRELATE IN WORKS OF MODERN WORLD LITERATURE
}

\author{
Feliks Shteinbuk
}

\author{
Comenius University in Bratislava, \\ Šafárikovo námestie 6, Bratislava, Slovensko, 81499 \\ e-mail:feliks.shteinbuk@uniba.sk
}

The article suggests the corporal-mimetic method developed in doctoral and post-doctoral studies as one of the theoretical and methodological propositions to confront modern challenges. This method to analyze fiction is a method of researching corporal-ontological basis of artistic discourse. The method was grounded in the notion of "corporal mimetism". It is one of the means to represent human corporal being in artistic discourse with the help of mimesis mechanism and corporal correlates conceptualized in philosophic context, which form a basis for creation of the dynamic complex image system of the literary work. It means that, in conditions of artistic discourse, any corporal category acquires the characteristic of topos which, in modern studies, is considered to be a "place of senses' developing".

The goal of the article is to determine the topological content of such corporal correlate as the correlate of suffering, as it is characterized by a radical, and at the same time, universal form, that is, by a traditional form of mental and corporal condition. The study is based on some representative works which belong to different cultural discourse.

The result of the application of the method of analysis to some works of modern world literature in terms of the suffering topos representation allows us to conclude that, on the one hand, at the present stage of literary development, the traditional correlate under study undergoes drastic changes up to dissipation and dialectically conditioned extinction. However, it continues to preserve the artistic ideas potential which provides a possibility for modern literature to keep philosophic meaningfulness, esthetic persuasiveness and emotional power.

On the other hand, the suggested method shows promising research potential since it allows analyzing not only national but also translated literary works in an effective way, and, hence, it can be extrapolated to other correlates in further research.

Key words: modern world literature, corporal-mimetic method, correlate, topos, suffering, dissipation. 